\title{
The rise and fall of Turkey's soft power discourse
}

Discourse in foreign policy under Davutoğlu and Erdoğan

Yohanan Benhaïm and Kerem Öktem

\section{(2) OpenEdition \\ 1 Journals}

\section{Electronic version}

URL: http://journals.openedition.org/ejts/5275

DOI: 10.4000/ejts.5275

ISSN: $1773-0546$

Publisher

EJTS

Electronic reference

Yohanan Benhaïm and Kerem Öktem, «The rise and fall of Turkey's soft power discourse », European Journal of Turkish Studies [Online], 21 | 2015, Online since 02 March 2016, connection on 16 February 2020. URL : http://journals.openedition.org/ejts/5275; DOI : 10.4000/ejts.5275

This text was automatically generated on 16 February 2020.

(c) Some rights reserved / Creative Commons license 


\title{
The rise and fall of Turkey's soft power discourse
}

\author{
Discourse in foreign policy under Davutoğlu and Erdoğan
}

Yohanan Benhaïm and Kerem Öktem

\section{Introduction}

1 Since the early 2000s, Turkey's profile on the world stage has been significantly transformed. From a doctrine of realism and Western orientation, Turkey's foreign policy elites as well as the leading cadres of the Justice and Development Party (Adalet ve Kalkınma Partisi, AKP) have changed the country's foreign policy outlook to one of active engagement with the world. The desire for regional leadership, patronage of the Muslim world, and presence in many of the major conflicts in its neighbourhood, however, soon turned into episodes of overstretch, hubris, and foreign policy debacles (Akkoyunlu et al. 2013). From the "Zero Problems Policy with Neighbours" and Foreign Minister Ahmet Davutoğlu's commendable "Strategic Depth" doctrine to a more belligerent stance towards Israel - temporarily boosting then Prime Minister Erdoğan's image in the Arab world - to Turkey's involvement in the Syrian War and its downgrading of diplomatic relations with Egypt it has only been a few years.

Parallel to this “rise and fall” dynamic of Turkey's foreign policy (cf. Bilgin 2015; Öktem 2015; Almassian 2014; Samaan 2013; Keyman 2012), the discourses surrounding actual policy have gone through comparable cycles. In this paper, we trace the boom and bust of Turkey's soft power discourse, which created a veritable dynamic of its own, particularly among academics and Turkish and American think tanks, and also in the media more generally. By doing so, we seek to understand the extent to which the discourse on "Turkish soft power" has been used in different ways by different actors and constituted a discourse of legitimization of AKP rule in the international arena as well as in Turkey.

3 We suggest that this discourse has gone through cycles of transformation according to the uses and interpretations of actors investing in this narrative during different 
political episodes, not only during AKP rule, but also in the period prior to this, following the end of the Cold War. The Turkish "soft power" discourse resembles an amorphous body of overlapping ideas and activities (also termed hyper-activism or pro-activism; cf. Keyman 2012), which eventually became generalised in academic circles and think tanks after its emergence in 2001. It is grounded in the idea that Turkey's civilian rule, democratic norms, and economic success are key elements for the diffusion of a positive image of the country abroad with the aim to create power capabilities where military power is not a viable option. Our aim is to critically reflect on how this branding strategy of "Turkey as a model" operated, when and on what scales it proceeded, and which goals it served. We are interested in the generation, modification, and operation of discourse in a mutually constituted field involving the academic and think tank community and political actors. We do not consider any one site of discourse production as the origin of this discourse or the main driver of its diffusion. These three poles can be considered as interconnected hubs of discourse production on Turkish "soft power" and the "Turkish model" and we can note the simultaneity with which they are promoting these discourses. We analyze the concomitance of discourse production in these different sites in order to highlight the mutually reinforcing dynamics of this triadic field. Our hypothesis is that academics, experts within Turkish and US think tanks, and AKP government officials have different interests in the promotion and dissemination of this discourse. This article paves the way for future research on the actual circulations of resources and agents structuring the relations between these three poles that we do not have the space to develop here.

On an international scale, the projection of soft power is of course not specific to Turkey's foreign policy. The very idea of soft power originates from the US within American foreign policy debate, and particularly from its realist version with Joseph S. Nye as its paragon (Nye 2015; 2004; 1990). From there, it was warmly received and gladly taken up by foreign policy analysts in other emerging middle powers like Brazil, Russia, India and China (the BRIC countries) as well as by Turkey. Meanwhile, the concept operates as a political indicator of the international league a country plays its diplomatic games in: it is aimed at indexing Turkey among other global leaders whose influence is grounded in soft power. If not on a par with the US, which according to Nye remains the one and only superpower in the world, and whether soft or hard (Nye 2015), Turkey has been trying to emulate the European Union and other emerging powers like the BRIC countries.

5 The specificity of the discourse on Turkish "soft power" is that it operates as a multirelational discursive tool. This discourse has often pertained to Turkey's function as a role model for its relations between the United States/the European Union and a fourth world region for which western appeasement is required. The Turkish model first emerged with reference to Central Asia after the Cold War. After a period or relative silence, which attested above all to Turkey's internal crises in the 1990s, the discourse made a forceful reappearance after 9/11 towards the Middle East (Iğsiz 2014). It subsequently peaked with the popular uprisings that shook the Arab world after 2011.

6 In Turkey, the use of "soft power" discourse has served the AKP's political agenda on multiple levels. Laying the emphasis on Turkey's leadership in the Middle East, and increasingly in the Muslim world, the ruling party has been able to reassert itself on the domestic scene. Discourse on the devotion of the AKP's external actions to the rise 
of Turkey's place in the world through the promotion of its values and the reconstruction of its national identity epitomizes the way in which foreign policy was turned into a campaign argument for Erdoğan's party throughout the 2000s, and particularly after the 2011 elections. Beyond its vote-winning aspects, "soft power" and leadership discourses were also a function and visible manifestation of what especially pro-AKP observers have called the demilitarization of Turkey's foreign policy. It legitimized the military's decreasing influence in domestic politics, while helping to marginalize the former bureaucratic elites.

7 Even if the "soft power" discourse, as it is discussed here, is not exclusive to the AKP's period in power, its central role in the political project of AKP power is. We can even go a step further and argue that the "soft power" discourse and its role in constituting a core linkage between two other discourses - domestic democratization and civilianization of politics - has occupied an existential place in (the now President) Recep Tayyip Erdoğan's strategy to establish a hegemonic political system and deepen his grip on power. As part of the aforementioned triad of interconnected discourses, the discourse of "soft power" helped obfuscate global views on the so-called civilianization process, which instead of democratising society led to new forms of authoritarianism, and in turn proved detrimental to the positive promotion of the country's image abroad.

8 Foreign policy failures and growing authoritarianism in Turkey since the beginning of the 2010s have rendered the discourse of "soft power" largely irrelevant. The emergence and diffusion of such a discourse in addition to its potential - if only for a limited time - to impress foreign policy elites at home and abroad and divert attention away from more pertinent domestic developments in Turkey remains a highly relevant question for consideration. Turkey under the AKP has never been the regional ordersetter that the former Foreign Minister Ahmet Davutoğlu has repeatedly claimed (Davutoğlu 2013, 2001; cf. Grigoriadis 2010; Murinson 2006). But it was able to project the discourse of its foreign policy for a few years, during which period the country did indeed amass symbolical power in the Middle East and beyond, even if, as we now know, this was a very shallow discourse that had the attraction of novelty, but little power of persuasion in the real world.

The empirical basis of this paper has been formed by a set of explorative case studies involving the institutions active in foreign policy debates and the outputs of thinks tanks and academic institutions in the period between the early 2000s and September 2014. Members of an interdisciplinary working group on "Turkish Soft Power" carried out these case studies. ${ }^{1}$ The research was based on a mixed methods approach with a particular emphasis on content analysis. This research method is content-sensitive and is used to describe and quantify phenomena (Miles, Huberman 1994; Denzin, Lincoln 2011; Schreier 2012). Content analysis can be used in an inductive or deductive way, with the former approach allowing for categories to be derived from the empirical field. We use this inductive trajectory to locate the places of production of "soft power" discourse, to understand the conditions of its production, and scrutinize its content. We have chosen to focus on "soft power", even though we use the related discourse of "Turkey as a model" as a comparative frame. As we demonstrate in our analysis, while "soft power" is above all an academic discourse, the "model debate" has remained limited in scholarly discussion, despite its significant presence in foreign policy and public debates on Turkey. 
10 We worked with a research design based on the three steps of preparation, organization, and reporting. The first stage of the process begins with the selection of the unit of analysis. In our case, the units of analysis were the texts made available on the websites of think tanks and government institutions, as well as on Internet search engines, such as Google and Google Scholar. Focusing on the Internet as a primary source of empirical evidence may arguably introduce biases into the process, which are almost impossible to control. ${ }^{2}$ In each of these units of analysis, we searched for literature referencing the two interrelated notions of "Turkish soft power" and "Turkish model". We searched texts in both English and in Turkish in order to examine the nature of the producers and to specify the publics targeted by these discourses.

11 More specifically, concerning the analysis of academic productions and the discourses of government institutions, we chose to explore regional and thematic categories. This allowed us to map the regions centralised by this discourse and the themes contained within it, as well as ascertaining the differences emanating from the divergent nature of the sources. These themes were visualised with the help of qualitative research and visualisation tools like Tagxedo.

12 We also have to acknowledge that our focus on terms like "soft power" and "Turkish model" constrains our analysis to foreign policy texts. The spread of the concept through other texts dedicated to public policy, cultural matters, Neo-Ottomanism etc., which implicitly describe soft power processes and therefore also contribute to this discursive thread without explicitly using the term (see, among others, Bingöl Macdonald 2012), cannot be accounted for in this study. While we are thus limited to the foreign policy literature in Turkey and abroad that explicitly cites the concept of "soft power', we do assume that such limitations are manageable for the analytical purposes of this paper.

13 Due to its exploratory character, the mixed methodology approach taken in this paper does not allow us to establish a full genealogy of Turkey's "soft power" discourse. It rather seeks to provide starting points for the analysis of how Turkey's "soft power" discourse has been constructed, which actors have been involved in this construction, what its most important contents have been, and to what extent this discourse contributed to the legitimization of AKP power.

14 The paper consists of three main sections each corresponding to the three sites of discourse production that we identified earlier. We first discuss the academic discourse of Turkey's "soft power" as it has been reflected in the global academic literature. We then examine the role of think-tanks inside and outside Turkey in the dissemination and adaptation of the discourse. Finally, we look into its use among foreign policy actors in Turkey, particularly by AKP governmental actors, specifically the former Foreign Minister (now Prime Minister) Ahmet Davutoğlu and the former Prime Minister (now President) Recep Tayyip Erdoğan.

\section{The emergence and rise of "soft power" as an academic discourse}

15 Turkey's "soft power" discourse has been clearly predicated on Joseph Nye's influential 1990 book Bound to Lead: The Changing Nature of American Power. Yet, it has taken more than a decade for Nye's ideas to trickle down into the foreign policy debate, which may 
have probably required a reminder in the shape of Nye's (2004) follow-up publication, Soft Power: The Means to Success in World Politics. When we examine the period from 2001 through academic publications made available on Google Scholar ${ }^{3}$, i.e. the period corresponding to the AKP in power, we see a very slow rise in the number of published academic papers (in Turkish and English combined) on Turkey's "soft power", beginning in 2005, accelerating in 2009, and reaching close to 80 papers in 2013 (Figure 1).

Figure 1: Academic articles containing the term "Turkish soft power"

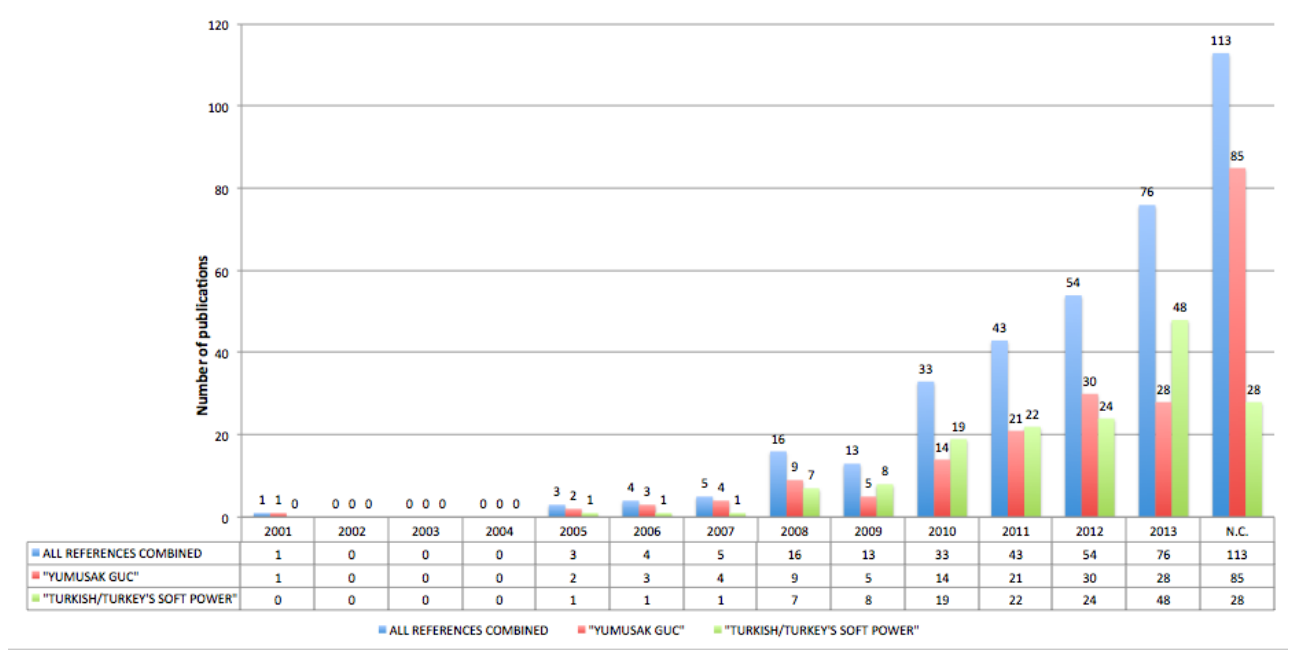

COMPILED BY JULIEN PARIS. BASED ON 371 GOOgLE SCHOLAR ENTRIES ON TURKEY'S "SOFT POWER".

This general trend is not surprising. Turkey's foreign policy actors became increasingly engaged in world politics and more visible, particularly after Ahmet Davutoğlu took over the office of the Foreign Ministry in 2009. With the increased outputs of progovernment think-tanks like SETA [Siyaset, Ekonomi ve Toplum Araştırmaları Vakfi, the Foundation for Political, Economic and Social Research] and through gatekeepers, such as Ibrahim Kalın (see box below), soft power-related terms gained much wider currency in foreign policy outlets. These gatekeepers are characterised by their ability to produce the narrative of "soft power" while participating in the construction of a complex institutionalized system of public and private partnerships charged with promoting it. Their circulation in Turkish and American think tanks and the position of their fields of expertise in public institutions is indicative of the personal interests that may become invested in the promotion of this discourse. They have also published academic or near-academic papers in journals such as Insight Turkey and Perceptions, and the journal of SAM [Stratejik Araștırma Merkezi, the Center for Strategic Research], the think tank of the Turkish Foreign Ministry.

Ibrahim Kalın graduated from Georgetown University and is a specialist in Islamic studies and International Relations. He was one of the first opinion leaders to promote the discourse of "soft power" from as early as 2006 in an article published in Zaman (Kalın Feb. 24, 2006, see also Kalın 2011). At the time of publication he was the founder and general coordinator of SETA, a leading pro-government think tank. In 2010, he was appointed to the Coordination Agency for Public Diplomacy [Kamu Diplomasisi Koordinatörlügü, KDK], launched under the Prime Minister in order to coordinate government efforts to promote Turkey's image. Between 2009 and 2012 he served as Senior Advisor to the Prime Minister Erdogan, before becoming the 
Deputy Undersecretary of the Prime Minister. In 2014, he became the spokesman for President Erdoğan.

It is worth comparing the evident presence of "soft power" discourse in academic works to the related discourse of the "Turkish model". While "soft power" was mentioned in 371 articles from 2001, references to the "Turkish Model" can only be found in 49 entries for the same research period (Figure 2). There is no comparative upward trend in the number of publications, even though there is a significant hike between 2011 and 2013, suggesting the start of an academic debate on the role for Turkey as a model for the future of countries destabilised by the Arab Spring. This number can be expected to remain at a relatively high level as the output of papers is likely to rise given the current political context and the failure of the discourse on the "Turkish Model", particularly in Syria, and following the Gezi protests in May-June 2013 and the breakdown of the Kurdish peace process in Turkey. For a comparison, please also consult Figures 3 and 4 .

Figure 2. Academic articles on the "Turkish Model"

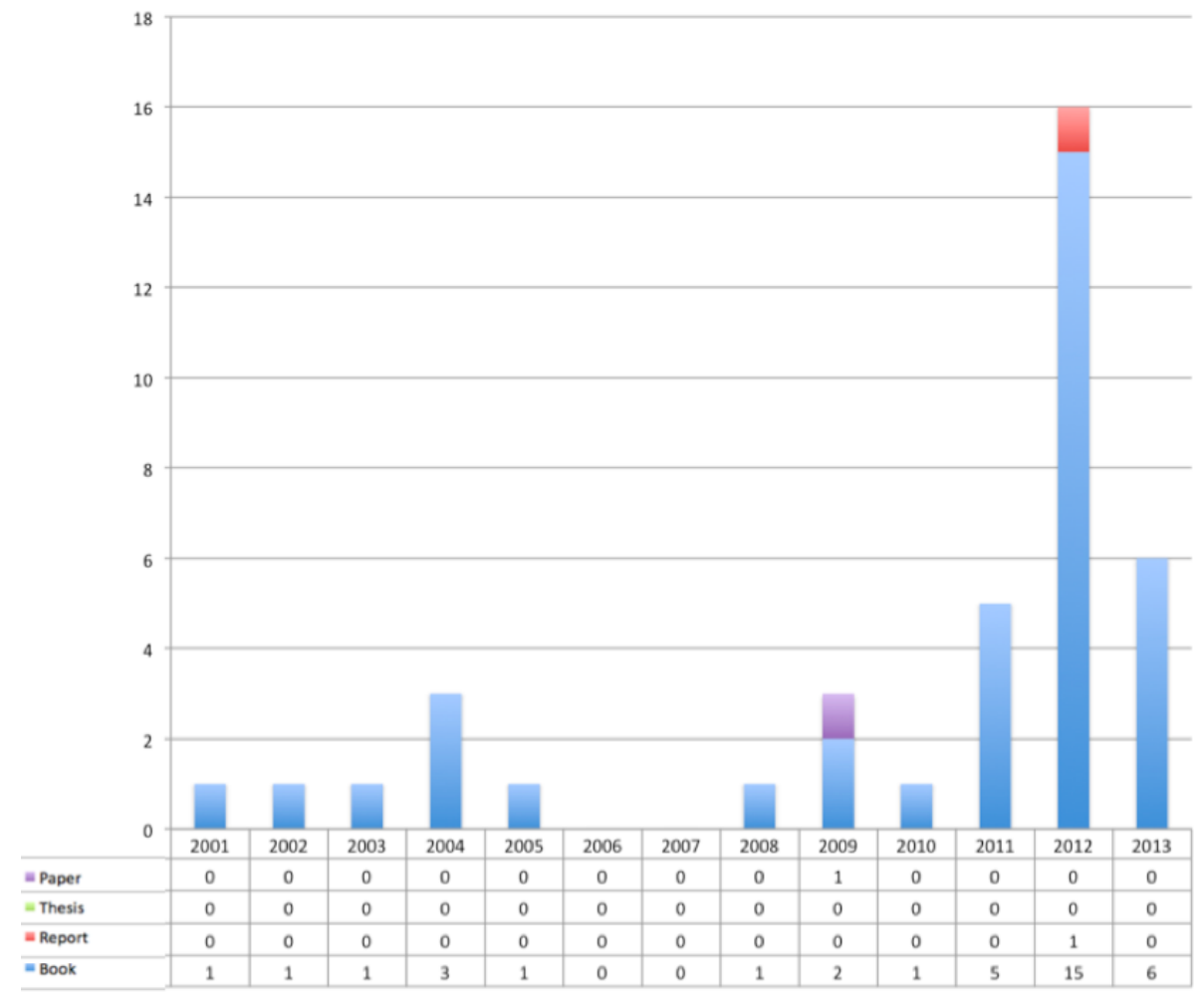

COMPILED BY JULIEN PARIS USINg GOOgLE SCHOLAR. BASED ON 49 ENTRIES ON THE "TURKISH MODEL".

In terms of the content of these articles, a perfunctory reading suggests that most academic papers on soft power involve more than one country, that is to say, they deal with Turkey's "soft power" in a particular world region combined with the role of the United States or Europe. Turkey's "soft power" discourse appears to be connected to the interests of the United States, and to a lesser extent the European Union, to influence parts of the world beyond their direct control via a more trusted regional leader, i.e. Turkey.

We can further explore the content of these publications by looking at the titles and words used in them. Figure 3 conveys a sense of the main constituents of "soft power" 
discourse. The results do tend to surprise to some extent as some of the key concepts one would expect to find - democracy, equality, justice - are largely absent from the studies. Rather, the most commonly used concepts are "foreign policy" and "foreign relations", and the most frequently referenced regions are the "Middle East", followed by the "European Union" (as a composite of "Europe" and "Union"), and the "Arab world". In terms of vocabulary, the following words are widely used: security, economy, strategy, culture, and energy. These results seem to corroborate the idea according to which the Turkish "soft power" discourse, as reflected in academic papers, is more concerned with promoting stability and security and with Turkey's role as moderating influence particularly in conflict-ridden third party contexts.

Figure 3: Frequency of key words used in academic publications on "Turkish soft power"

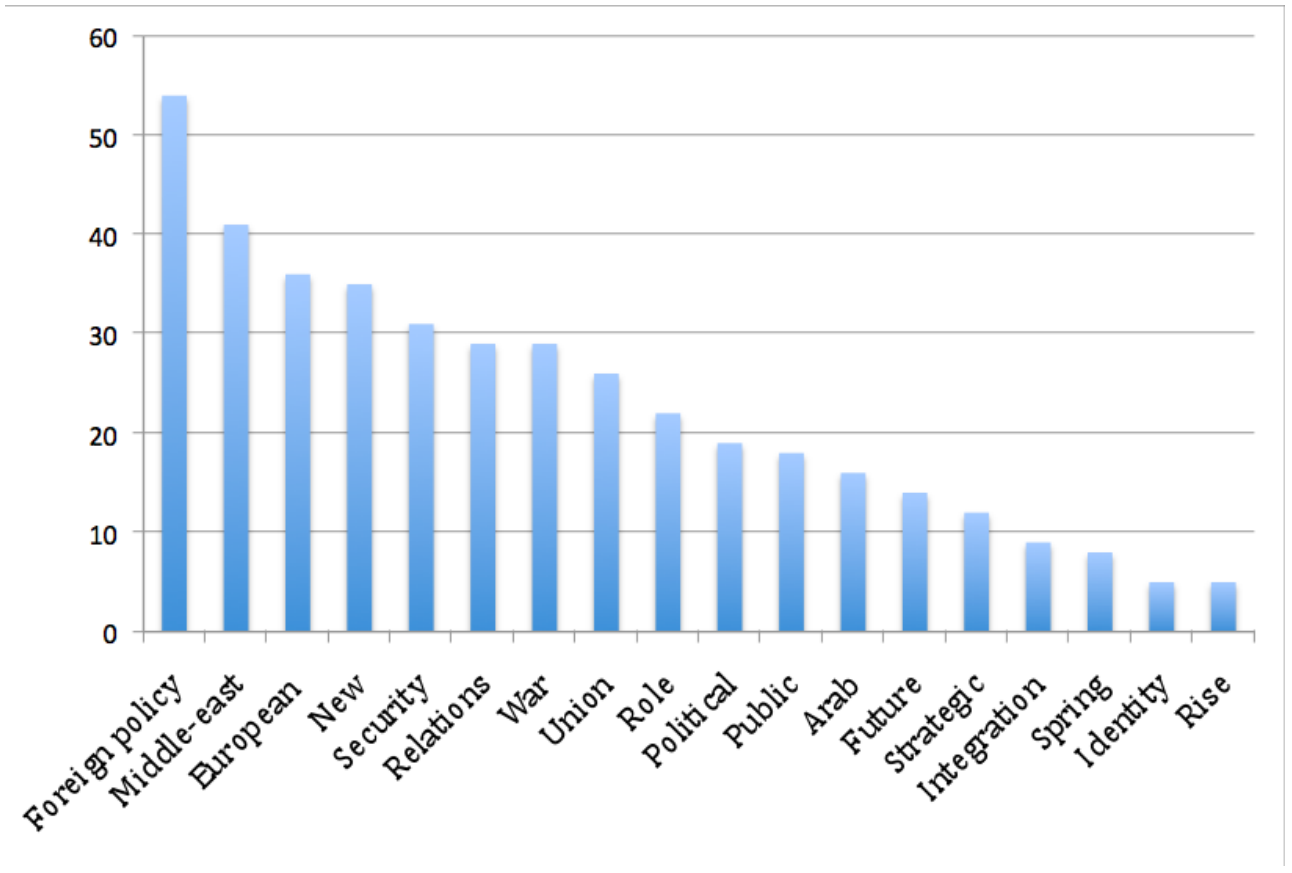

COMPILED BY JULIEN PARIS. BASED ON THE TITLES OF 365 PAPERS REFERENCED BETWEEN 2001 AND 2014 AND TRANSLATED INTO ENgLISH. THE WORDS “SOFT POWER”, “TURKISH”, AND “TURKEY" HAVE BEEN EXCLUDED FROM THE TABLE DUE TO THEIR HIgH FREQUENCY OF OCCURRENCE. 
Figure 4: Frequency of key words used in academic publications on "the Turkish Model"

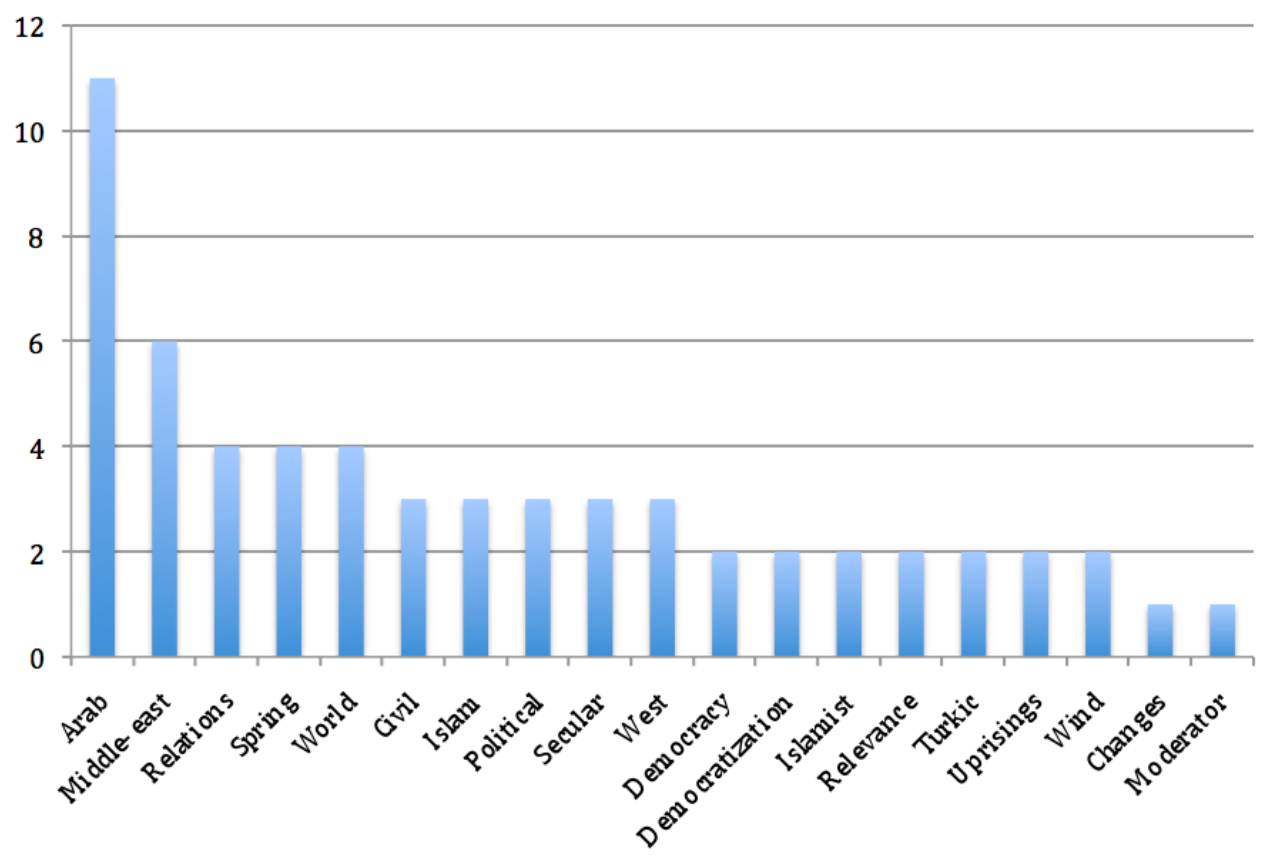

COMPILED BY JULIEN PARIS. WORD CLOUd BASED ON THE TITLES OF 49 DOCUMENTS REFERENCED BETWEEN1978 AND 2014 AND TRANSLATED INTO ENgLISH. THE WORDS "TURKISH MODEL", "TURKISH", AND “TURKEY" HAVE BEEN EXCLUDED FROM THE TABLE, DUE TO THEIR HIgH FREQUENCY OF OCCURRENCE.

A comparison between the content of "soft power" discourse and "Turkish model" discourse here is quite insightful (Figure 3 and Figure 4). The former is much more widely spread both in terms of world regions and conceptual references with Europe, the Middle East, and Africa represented. "Turkish model" discourse, as represented in Figure 4, is concerned with democracy and democratization in the Middle East after the Arab spring with extensive references made to Islam, Islamism, and secularism, and the role of Turkey as moderator. This figure thus confirms our working hypothesis that a central dimension of the "Turkish model" discourse is its role within US and EU debates concerning Turkey's role in the Middle East after the popular uprisings in the Arab world. One of the possible explanations for the growing importance of Turkish "soft power" and "model" debates in the 2000s may be the increasing mutual dependence between academic institutions, thinks tanks, and government agencies. This interdependence seems to have contributed to the blurring of lines between nonpartisan scholarly research, academic research with a (hidden) political agenda, and outright partisan work to the point of devaluing the academic endeavour as a whole.

\section{Turkish and American think tanks advocating for the "Turkish model"}

21 As we established in section one, "soft power" discourse and the "Turkish model" debate are two distinct if interrelated discourses on Turkey and its foreign policy. Discursive developments since the 1990s provides us with an insight into the workings of US-Turkey bilateral relations and the mode whereby this field of expertise is structured in these two countries. 

reconfigurations of the post-Cold War era. During the Cold War, Washington's containment policy against Moscow was defined by a reactive doctrine, described by the International Relations (IR) theorist Georges Kennan as an "adroit and vigilant application of counter-force at a series of constantly shifting geographical and political points, corresponding to the shifts and manoeuvres of Soviet policy" (Kennan 1947). Due to its location, Turkey represented one of these geostrategic points and maintained strong economic and military ties with Western institutions, such as NATO, and especially with the United States. The end of the Cold War, hence, constituted a critical period of uncertainty for Turkish decision makers, as it put into question the "strategic rentier" (Bozdemir 1991) position of their country. In the same period, Turkey also experienced two main setbacks to its European ambitions in 1987 and $1989 .{ }^{4}$ As a countermovement to these challenges, Ankara was also able to take advantage of the implosion of the Soviet Union to reaffirm its strategic importance on the international scene and especially to the United States.

The collapse of the Soviet Union led to the independence of five Turkic republics in Central Asia and the establishment of new states in the Caucasus. American and Turkish foreign policy actors quickly labelled Turkey as a model for these countries on the basis of three elements: firstly, Turkey was seen as a model of development for Central Asian economies willing to embrace capitalism after seventy years of a centrally planned soviet economy; secondly, it was suggested as a model of democratization; and thirdly, Turkey was represented as a secular model of modernization for Muslim-majority countries, unlike other actors such as Iran (Aydın 2003; Balc1 2005). In addition, the underlying argument of shared history and culture between Turkey and the Central Asian Republics coincided with Huntington's emphasis on civilizations in world politics, an influential perspective among decision makers and analysts in the US, particularly under Presidents George H. W. Bush and later George W. Bush. This may have thus played a role in the popularity of the notion of the "Turkish model" during the early 1990s. Nevertheless, it quickly became apparent that Turkey lacked the capacity to fulfil this role due to its own domestic political and economic instability.

Despite the disillusionment over Turkey's failure as role model for the Central Asian states, the idea of a Turkish model had spread to other areas by the late 1990s. As in the case of Central Asia, it was possible to witness the development of this discourse in regions where US interests were at stake and where the State Department remained wary of the influence of non-allied states. While the "Turkish model" was promoted in Central Asia to counter Iranian influence and isolate the former Soviet republics from Moscow, in the Muslim world it was promoted as an alternative to the attraction of political Islam. In a speech held in 1999 at the Washington Institute, the Turkish Prime Minister Bülent Ecevit stated:

Turkey is, I believe, a model for Islamic countries (...) I believe that Turkey's example has played an important role in this respect, because the Turkish experiment has proven that Islam can be compatible with modernity, with secularism, and with democracy. (Ecevit 1999)

It is important to note that Ecevit gave this speech in Washington with the intention of strengthening Turkey's economic partnership with the US after the devastating earthquake that struck the country earlier in the year. In the American context, the welcome reception of Ecevit's words was facilitated by Washington's increasing

European Journal of Turkish Studies, 21 | 2015 
concern about the potential threats posed by 'Islamist terrorism'. The two attacks on the US embassies in Nairobi and Dar Es Salam in the previous year led to strategic discussions on the Muslim world and Turkey's role as "pivotal state" within it. ${ }^{5}$

Figure 5: American think-tank publications on "Turkish soft power" and "Turkish model"

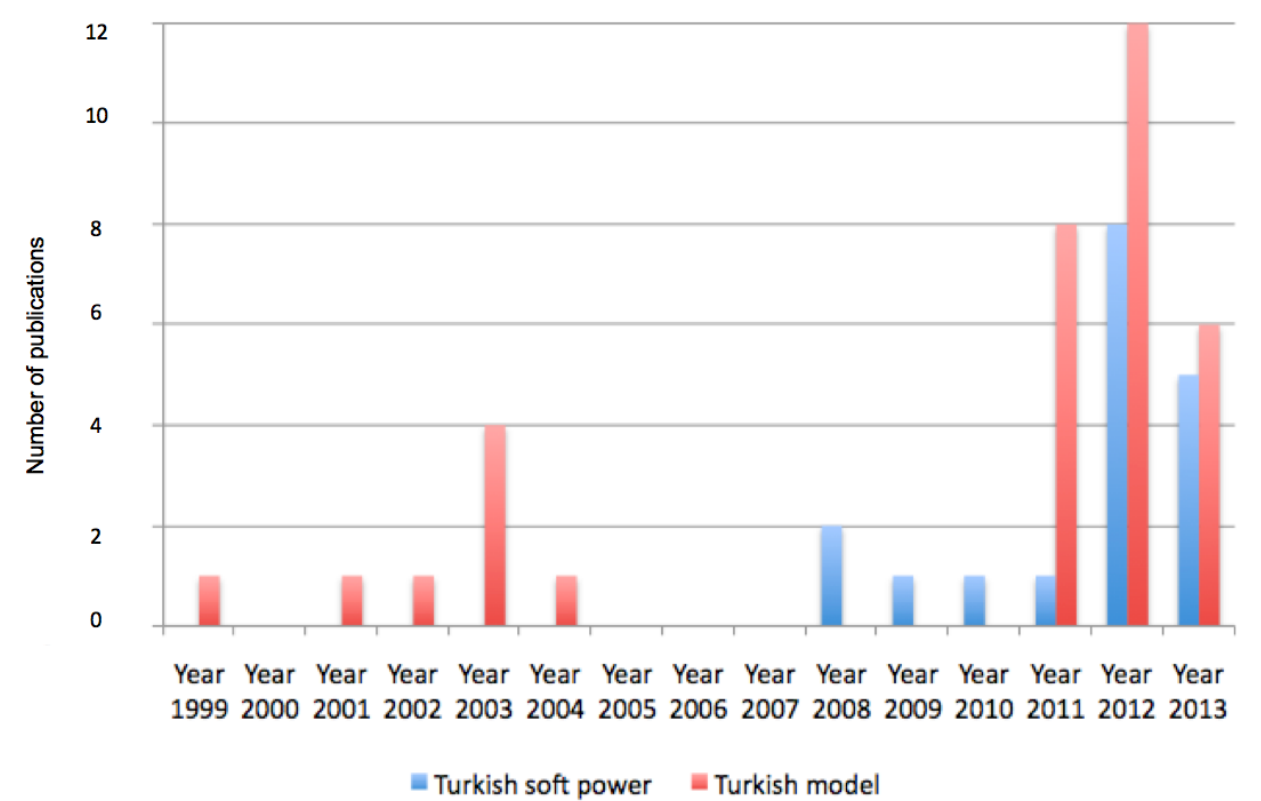

COMPILED BY JEAN-BAPTISTE LE MOULEC AND YOHANAN BENHAIM IN FEBRUARY 2014. RESEARCH BASED ON THE WEBSITES OF EIGHT LEADING US THINK TANKS SPECIALIZING IN FOREIGN POLICY: THE CARNEgIE ENDOWMENT FOR INTERNATIONAL PEACE, THE COUNCIL OF FOREIGN AFFAIRS, BROOKINgS INSTITUTIONS, THE WASHINGTON INSTITUTE, THE CENTRE FOR STRATEgIC AND INTERNATIONAL STUDIES (CSIS), THE MIDDLE EAST FORUM, THE WOODROW WILSON CENTRE, AND THE JEWISH INSTITUTE FOR NATIONAL SECURITY. TOTALS PERTAIN TO THE WHOLE PERIOD BETWEEN 1999 AND 2014.

The geographic shift from Central Asia to the Islamic world correlates to the reorientation of Turkey's globally promoted identity from Turkishness to (Turkish Sunni) Muslimhood. It also suggests that this shift is part of the structural pattern of Turkish-American relations, which develops in response to the international and domestic challenges faced by the two partners. The "Turkish model" cycle is consequently an expression of the evolving nature of this bilateral relation. The post-9/11 international context in combination with the first AKP government in Turkey and the US invasion of Iraq, opened a new phase in the evolution of the "Turkish model" discourse. Here, it is worth drawing attention to the frequency with which this concept appeared in the publications of leading American foreign policy think tanks (Figure 5). The debate on Turkey's role model status was at the time oriented towards finding a resolution to the so-called "clash of civilisations" with Turkey positioned as a "bridge country between West and East" (Iğsiz, 2014). In the late 2000 s, the debate progressed and the first reports and articles on "Turkish soft power" were published, alongside the development of the discussion on the "Neo-Ottomanist" reorientation of Turkish foreign policy. With the Arab uprisings at the beginning of 2011, the debate on the "Turkish model" peaked reaching a new level. The majority of articles debated whether Turkey and the AKP could represent a model for Tunisia, Libya or Egypt and their respective Islamist parties. Since mid-2012, discourses on the 
"Turkish model" and "Turkish soft power" seem to have overlapped, albeit in the form of a critical discussion against the viability of both approaches. In particular, the deteriorating situation in Syria and Ankara's inability to provide a constructive answer to the crisis have called into question their relevance. The harsh repression of the Gezi Park demonstrations by the Turkish police in spring 2013, triggered further critical publications describing the AKP government's increasingly authoritarian stance as a threat to Turkey's stability and influence in the Middle East, as well as its reliability as an ally of the US. Finally, the AKP's authoritarian shift and its decision to terminate the peace process with the Kurdish movement in Turkey has led even the most proactive supporters of the ruling party to abandon the discourse on Turkey's "soft power".

The study of the publications of leading Turkish think tanks is enlightening in this context. When we compare the occurrence of the concepts of "model" and "soft power" we see that the notion of the "Turkish model" still dominates (Figure 6). It is possible to witness a similar and even more accentuated trend in American think tank production. To explain the scope of the debate on the "Turkish model" among American think tanks we can hypothesise that beyond Turkey, it is the American model that is at stake in an important part of this literature: the promotion of democracy, capitalism, and secularism via the example of Turkey is first and foremost a way for the United States to promote its interests. This has been especially true of the praise of the "Turkish model" in American think tanks by neo-cons of the George W. Bush administration like Paul Wolfowitz. During a speech at the Fifth Turgut Özal Memorial Lecture at the Washington Institute in March $2002^{6}$, a few months after the beginning of the ISAF operation in Afghanistan, Wolfowitz stated:

In the United States, we understand that Turkey remains on the frontlines of the war on terror. And we also understand that Turkey is a model for those in the Muslim world who have aspirations for democratic progress and prosperity. Turkey gives us an example of the reconciliation of religious belief with modern secular democratic institutions.

This relationship between US foreign policy and the discourse of the "Turkish model" at a time when the neo-cons were promoting a vision of American hegemony in the Middle East, contributed to paranoia in Turkey about the influence of Washington in the region and its alleged support of the AKP government. However, such judgement fails to account for the complexity of this discourse, which cannot be reduced to a simplistic expression of the domination of the centre over the periphery. Indeed, the producers of discourses on Turkey within Turkish and American think tanks are characterized by their mobility. There is a remarkable pattern of circulation between different institutions located both within the United States and in Turkey. A rapid glance at the analysts working in American think tanks on Turkey indicates that the majority are of Turkish origin and move between universities and think tanks in the US and Turkey. Some analysts could qualify as gatekeepers of this particular field of expertise as they have been responsible for producing reports on Turkey for several American think tanks since the beginning of the 2000s. In addition, this system is characterised by its permeability and especially by its connections with academic and political fields, which further enhances the circulation of actors and thoughts within this system of knowledge production.

This articulation between the political field and the local context also explains the comparative differences between publications on Turkey produced by American and Turkish think tanks. When the first revolts started in Tunisia and Egypt, Turkish 
officials refrained from promoting the vision of Turkey as a model. In a conference organized by the Abant Platform ${ }^{7}$ in December 2011, Erşat Hürmüzlü, the Middle East special advisor to the then Turkish President Abdullah Gül, stated that Turkey should not be considered as a model, but as a source of inspiration to neighbouring countries (Radikal December 3, 2011). This insistence on the fact that Turkey should not represent a model for the countries experiencing the "Arab Spring" may have been based on the determination not to repeat the mistakes made in Central Asia in the 1990s, when Turkish foreign policy failed to live up to its ambitions of regional leadership.

This cautious attitude also marked an attempt to promote Turkey's "soft power" capabilities. Contrary to the model narrative, "soft power" discourse promoted Turkey as a dynamic player in regional politics, rather than as a country distinguished by its essence as Turkish or Muslim. Laying the emphasis on Turkey's "soft power" could be interpreted as an expression of preference of what Turkey does rather than what it is, as remained the case until the authoritarian and identitarian turn in Turkey after the 2011 elections. This was also a way of enhancing its actions and autonomy towards other major actors in world politics such as the United States. Indeed, this also constituted the main paradox of this discourse: while the "model" and "soft power" discourses were framed by the mutual interests of Turkey's American ally, one of the main sources of Ankara's popularity continued to reside in its ability to emancipate itself from Washington and act as an independent power vis-a-vis Israel. While the debate on the "Turkish model" within Turkish think tanks was oriented towards a Turkish-speaking audience, the "Turkish soft power" debate was conducted in English in order to reach an international public (Figure 6). This discrepancy allows for some preliminary conjectures to be made: Turkey's foreign policy actors have been cautious to avoid the model debate in outputs geared towards an English-language audience, which of course also includes readers in the Arab and Muslim world where Turkey has been seeking to build-up its power capacities. For the Turkish-speaking audience, however, Turkey's role as model has been used much more permissively and sometimes in a nationalist context. 
Figure 6: Language used in Turkish think tank publications on "Turkish soft power" and the "Turkish model"

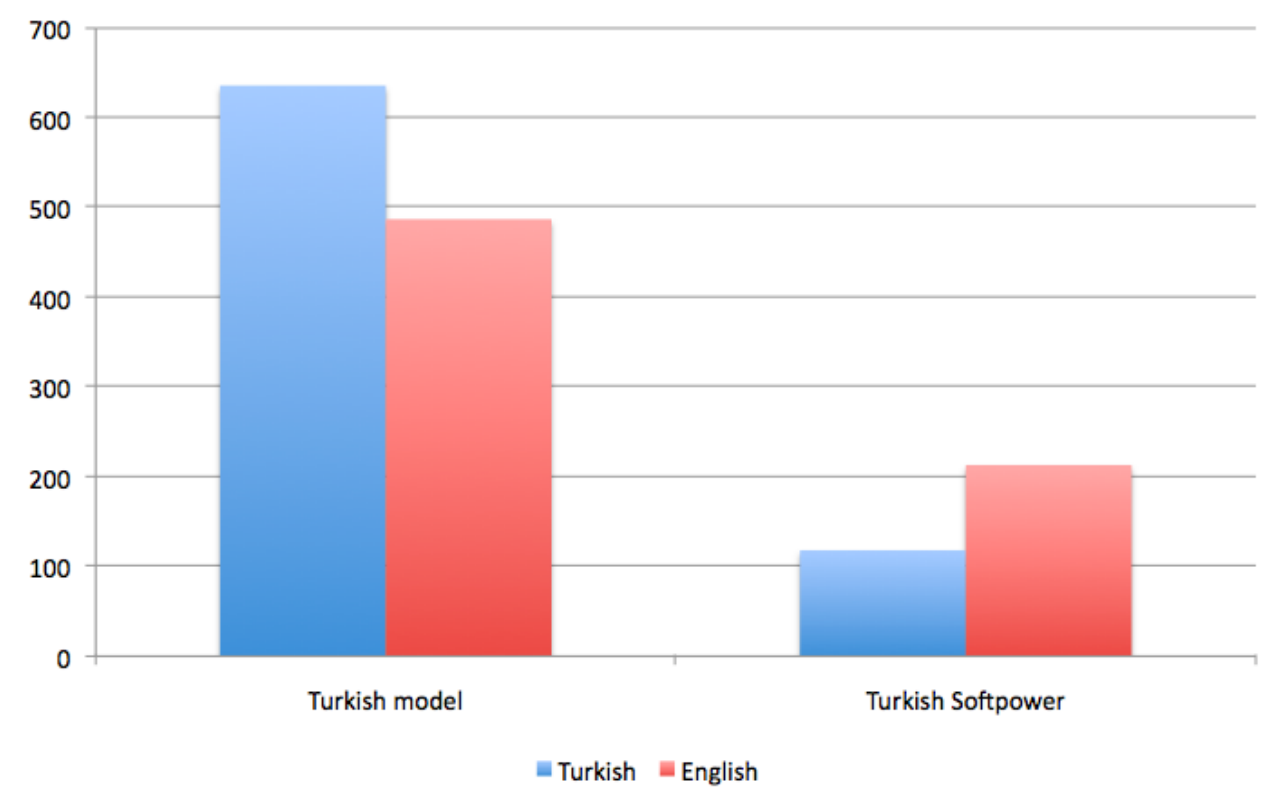

COMPILED BY YOHANAN BENHAIM IN APRIL 2014. BASED ON RESEARCH ON THE WEBSITES OF SEVEN OF THE LEADING FOREIGN POLICY THINK TANKS IN TURKEY (ORSAM, USAK, TESEV, SETA, SDE, TEPAV, BILGESAM).

Finally, "Turkish model" and "Turkish soft power" discourses are not equally dispersed among Turkish think tanks. Indeed, TEPAV and SETA represent the two think tanks are at the forefront of promoting the idea of Turkish "soft power". This is certainly not a coincidence. TEPAV is the think tank of the Turkish Union of the Chamber of Commerce, a body that is benefiting from the development of trading state foreign policy (Kirişçi 2009) and willing to develop a positive image of Turkey in order to attract foreign investments. SETA on the other hand is known in the domestic arena and especially in Washington for its strong connections to the AKP government and its foreign policy. The entangled relationship between economic and political interests and think tank productions also serves as a reminder of the lack of autonomy of a large part of the Turkish think tank community from the state. Such a lack of autonomy is, of course, a phenomenon not limited to Turkey alone. Yet, since the authoritarian shift of the AKP government in 2011, it has become particularly accentuated. Therefore, the growing importance of "Turkish model" discourses in Turkish and American think tanks seems to be directly related to the fact that some of the experts promoting this discourse were committed to the foreign and domestic political agendas of Ankara and Washington.

\section{The promotion of "soft power" discourse by Turkish foreign policy actors and the AKP government}

Having discussed the emergence of "soft power" discourse in academia and thinktanks, we shall now turn to examine its use by Turkish foreign policy actors and the AKP government. Specifically, we will focus on the use of this concept in the speeches of the former Foreign Minister (and current Prime Minister) Ahmet Davutoğlu, and the 
former Prime Minister (and current President) Recep Tayyip Erdoğan. We chose these two actors as they are the most authoritative actors of the AKP government and Turkish foreign policy abroad. We will firstly examine the presence of the term "soft power" on the websites of the Turkish Ministry of Foreign Affairs (MFA). ${ }^{8}$ In a second step, we will submit Foreign Minister Ahmet Davutoğlu's speeches to closer scrutiny. In both cases, the content associated with "soft power" is shallow, but a remarkable distinction can be made between a language concerned with IR theory on the one hand (Ahmet Davutoğlu), and one that is much more openly nationalist, imperialist, and panIslamist on the other hand (Recep Tayyip Erdoğan). On the website of the Ministry of Foreign Affairs, Turkey's "soft power" is primarily characterised as consisting of three key characteristics: Democracy, Economy and Trade, and European Soft Power, with the first two voiced consistently and independently of the audience and location of its author. Other constituent elements or sources of Turkey's "soft power" are presented as Turkey's liberal visa regime, it's inspiration for and influence in the Muslim world, the role of history, and Turkey's actions as an 'emerging donor'. In (only) one background paper, the key actors of "soft power" are mentioned as the Turkish Radio and Television Corporation's (TRT) foreign language programmes, Turkish Airlines, the Turkish Development and Cooperation Agency (TIKA), and the Presidency for Expatriate Turks.

33 A truly intriguing aspect of the "soft power" debate, which may also hint at the rather wide applicability of the term by the Ministry of Foreign Affairs and Ahmet Davutoğlu, is perceptible in the emphasis on a new discourse and diplomatic style in Turkey's Foreign Policy in the following quote:

We do not make threats... (but use) a language that prioritizes civil-economic power. (Ahmet Davutoğlu, Foreign Policy, May 20, 2010).

Davutoğlu seeks to distinguish himself from earlier more conventional forms of foreign policy and the militaristic mind set, which dominated Turkey's relations with the world before $2002 .{ }^{9}$

\section{Democracy and economy}

The following two quotes illustrate the consistent references to Turkey's democracy and its assumed power of attraction for countries in its neighbourhood:

We are cognizant of the fact that our democracy is our biggest soft power. (Ahmet Davutoğlu at a meeting with EU Ambassadors, May 8, 2009).

Though there is ample room for improvement, our democracy inspires many in our neighbourhood and constitutes the backbone of our growing soft power. (Naci Koru during a lecture at Stanford University's Business School, February 13, 2013).

The commitment to the advancement of democracy and economic development is also apparent in Ahmet Davutoğlu's interview with the American University in Cairo Review, conducted before President Mohammed Mursi's ascent to power. He combines many of the sources of Turkey's "soft power" in one single sweep, prioritizing location, economy, culture, and democracy.

Our geostrategic location, booming economy, ability to understand different social and cultural dynamics in a vast geography and commitment to advance democracy... domestically and internationally are all important assets... The key word defining Turkey's relations with the Arab countries is not "hegemony" but 
"mutual cooperation". (Ahmet Davutoğlu, American University of Cairo Review, February 13, 2012).

\section{Arab affairs.}

\section{European and Turkish soft power}

Turkey-EU relations and European "soft power" as both a condition and result of Turkey's prospective membership is also prominent on the MFA's website. However, it is crucial to consider that all speeches and articles referring to this relationship are geared exclusively towards European audiences. One exception aside, MFA documents do not mention Turkey's relationship with the EU when audiences outside the EU are in question.

The relation between Turkish and European "soft power" is well represented in the below quote, which is also used verbatim in several other speeches in the samples taken of Davutoğlu and others:

Europe and Turkey... share a truly common vision for the future of our continent: A Europe that strengthens its soft power and advances its universal values; that promotes diversity: that is much more influential in global politics. (Davutoğlu during a speech at the Nueva Economia Forum in Madrid, November 16, 2009).

The importance of Turkey for the EU and vice versa can also be found in the speeches of the former Minister of Foreign Affairs, Ali Babacan:

Turkey's EU membership will considerably increase its soft power and appeal in expanding civil and human rights in the Islamic world. ... Turkey will become Europe's gateway to a wider world and a portal for our common values and shared ideals that will have a more receptive audience in the Middle East. (Ali Babacan, October 2, 2007).

Babacan discusses the role of Turkey's EU membership as a source of "soft power" for the EU as well as for Turkey by employing the "gateway to the Middle East" metaphor. In this reading, Turkey's "soft power" will rise as the direct result of EU membership, Turkey will become a hub of attraction for the Middle East and will assume responsibility for "translating" European values to the Muslim world. In exchange, the EU will be able to better understand and cooperate with the Middle East thanks to Turkey's "more receptive audience in the Middle East".

\section{Beyond Europe}

As one would expect, MFA representatives adjust their examples to suit their audiences. While they do not refer to the European Union when speaking in Brazil or Africa for example, they do emphasise other issues such as Turkey's role as a donor of development assistance and its liberal visa regime.

We used our visa policy as a tool of increasing soft power capability, lifting visa requirements with more than 30 countries in the last 5 years. In addition to its political and cultural benefits, these agreements boosted our tourism. (Naci Koru, during a meeting with Turkish Honorary Consuls in North and South America, April $15,2013)$. 
illy, a recurring theme is the historical foundations of Turkey's "soft power". An MFA paper on Turkey and NATO explains Turkey's importance for NATO in the following fashion:

Turkey mobilizes its "soft power" by means of using its deep historical ties with populations and countries in the wide geography where NATO acts.

The quote here refers to NATO's missions in Bosnia, Kosova, Macedonia, and Afghanistan, conflicts in which Turkey has indeed been able to use its religious and cultural identity to establish relations of trust with local Muslim populations.

\section{A closer look at Davutoğlu's speeches}

Based on an analysis of all 75 publicly available speeches of the Foreign Minister, ${ }^{10}$ we can see some degree of overlap with the "soft power" discourse of the Ministry of Foreign Affairs, in addition to some points of deviation. Figure 7 represents his core vocabulary. While the economy and cooperation tops the list, the emphasis on democracy is comparably less pronounced than on the ministry's website, and it is used with the same frequency as Islam.

Figure 7: Turkish Foreign Minister Ahmet Davutoğlu's core vocabulary - Top 15 Keywords

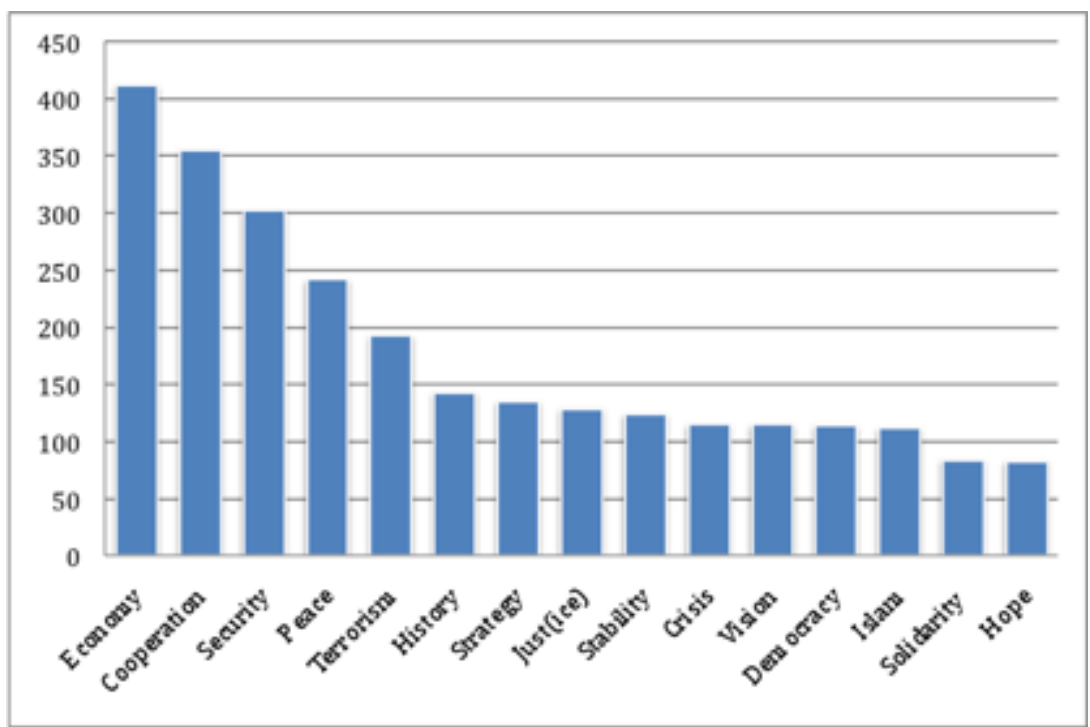

COMPILED BY KEREM ÖKTEM. BASED ON 75 SPEECHES MADE BY FOREIGN MINISTER AHMET DAVUTOĞLU.

Davutoğlu's vision emerges as less Euro-centric and is certainly not geared towards the promotion of democracy. Economic and political cooperation and security are at the heart of his engagement with the world, not democracy or the rule of law. There is no reference to human rights, and most interestingly neither to the explicit terms "soft power", nor "strategic depth". His speeches, however, can be seen as operationalizations of these concepts, which are implicit in his public statements.

Seeking to break down Davutoğlu's understanding of Turkish foreign policy, the frequency of city names referred to in his speeches are examined (Figure 8). ${ }^{11}$ What is truly striking here, is that the most often cited city by the Foreign Minister in his programmatic speeches is in fact Istanbul. Considering that Ankara is the country's 
capital and only comes second, a strong emotional attachment to Istanbul as the symbol of something larger than the Turkish Republic and its capital may be detected here. Istanbul was the capital of the Ottoman Empire and, at least in Davutoğlu's mental map, is the leading city of Islamic cosmopolitanism, the desired conceptual image Turkey wishes to represent to the world. The faint hint of the capital of the Islamic Caliphate is inherent in the notion of Muslim cosmopolitanism. Davutoğlu himself has never explicitly talked about the re-establishment of the Islamic Caliphate as a foreign policy goal, but several commentators in newspapers close to the AKP government, such as Yeni Akit and Yeni şafak, have made this connection quite aggressively (i.e. Köse August 26, 2014).

The political geography and the ideological frame emerging from this analysis is compelling: it is an extended universe of overlapping spheres of influence with Istanbul at its centre. After Ankara, Brussels and New York come third and fourth, reflecting the relative importance of Turkey's two leading allies. The remainder are a mix of capital cities located in Turkey's neighbourhood with Jerusalem, Baku, Cairo, Sarajevo, and Damascus the most cited. Their relative importance accurately reflects the key areas of Turkish foreign policy interests under the Justice and Development Party, ranging from the issue of the occupation of Palestine to close petro-ethnic ties with Azerbaijan, criticism of Egypt after the ouster of President Mursi and the suppression of the Muslim Brotherhood, the "emotive" relation with the Muslim element of BosniaHerzegovina, and the conflict with Syria's President Basher Al Assad.

The mental map of Ahmet Davutoğlu, visualized in Figure 8, also reminds us of the continuities and ruptures of Turkey's foreign policy and its strategic alliances. The United States and the European Union have been strategic allies since the end of World War Two - if now contested and disliked - while Azerbaijan became an ally in the 1990s due to successful Azeri policies based on ethnic ties and energy dependence. Jerusalem, representing both occupied Palestine and Israel's policies, is a core theme of Davutoğlu's Islamist ideology, while Sarajevo stands for the re-imagining of Turkey's sphere of influence through a Neo-Ottomanist and Pan-Islamist conceptualisation of geopolitics. 
Figure 8: Cities mentioned in Turkish Foreign Minister Ahmet Davutoğlu's speeches

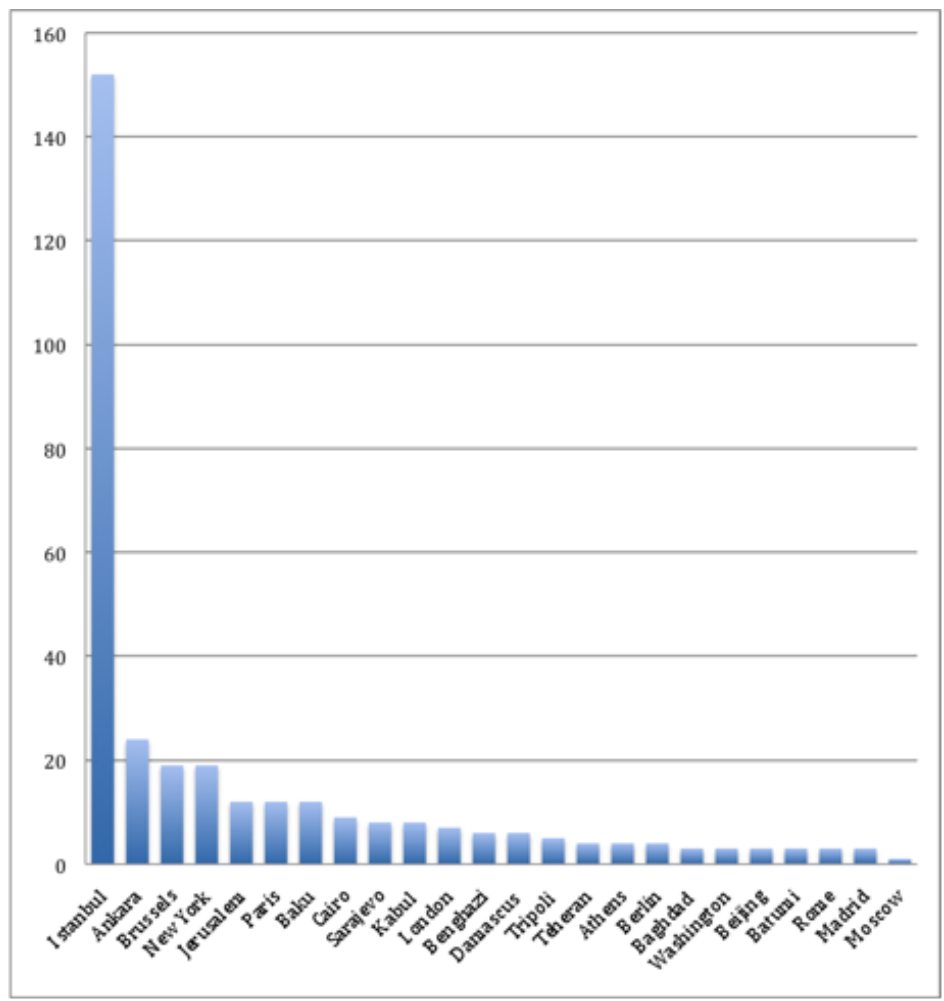

COMPILED BY KEREM ÖKTEM. BASED ON 75 SPEECHES BY FOREIgN MINISTER AHMET DAVUTOĞLU.

\section{Recep Tayyip Erdoğan as Prime Minister}

Recep Tayyip Erdoğan's speeches differ from those found on the MFA website in language, content, and emotional appeal. His language is emotive, suffused with neoOttomanist references and adorned with nationalist fervour. "Soft power" emerges as one of many ideas, which he appears to use with relatively little interest in detail. In two out of three speeches, he highlights the agencies under his control as prime actors of Turkey's "soft power".

In the last eight and a half years, we have emphasised this soft power dimension in foreign policy. Inspired by the unique resources of our history, our culture, and our civilisation, we are engaged in a hard struggle to have an impact on processes, to contribute to solutions for all questions on the regional and global scale. ... In addition, we disseminate Turkey's soft power, Turkey's message of peace to the whole world through TIKA, the Yunus Emre Institutes, the TRT, the Presidency of Turks Abroad and Related Communities. (Prime Minister Recep Tayyip Erdoğan at the conference of trade attachés, April 25, 2011).

In another context, Erdoğan extends the term "soft power" to re-frame Ottoman history as an example of flexible power:

Next to hard power, there is now soft power or with a more correct term, "flexible power'. ... The term flexible power may be a new, modern term, but we have believed throughout our history that the pen is mightier than the sword and the doors that cannot be opened by the sword can be opened with a pen. Our historical buildings, scattered over three continents, our tokens from the past, are the most concrete expressions of this. (Erdoğan at the 144 th year celebrations of Turkey's Red Crescent Society, August 11, 2012). 
And finally, at a Meeting of the High Council for Science and Technology, he distances himself from the idea of Turkey as a solely "soft power" actor and calls for the rise of a national arms industry with the potential to amass greater deterrent power.

A soft power claim that is not supported by deterrent power is only talk. Turkey is now in a period in which potentials are transformed to action. (Meeting of the High Council for Science and Technology, January 15, 2013).

The three quotes suggest primarily that for Erdoğan, "soft power" is not an indispensable ingredient of his political vocabulary: "soft power" can become "flexible power", and "flexible power" can become "deterrent power". In Erdoğan's speeches, it is the overarching importance of the Ottoman Empire and the role of civilization (read religion) that makes for Turkeys "unique" place in the world.

All in all, the Turkish Ministry of Foreign Affairs, as represented in this sample, perceives Turkey's "soft power" as emanating largely from Turkey's democratic credentials, its vibrant economy, and its relations with the European Union, even though the latter seems to be an argument reserved for European audiences only. Turkey is represented as a responsible, "virtuous" power (former President Abdullah Gül) that mobilizes history, culture, identity, and geographic location to advance democracy and the economy in Turkey and abroad. References to Turkish aspirations for regional leadership are muted and the language is generally diplomatic and well considered. Significantly, the terminology of "soft power" is employed coherently throughout the research period and it is only the references to Europe that have declined in frequency over the last few years. With this quality, the MFA website stands in contrast to both the public speeches of Foreign Minister Davutoğlu, which depict Turkey as a civilizational power particularly in the Balkans, and to the speeches of then Prime Minister Erdoğan, which are steeped in neo-Ottomanist references, nationalist fervour, shifting terminology, and changing realpolitik choices. Intriguingly absent is any reference to the United States, which we earlier identified as one of the main drivers of the Turkish model discourse.

Since the Gezi protests in May and June 2013, much of the foreign policy language emanating from Ankara has, of course, changed considerably. This change has been much more profound in the case of Foreign Minister (and later Prime Minister) Ahmet Davutoğlu, who made a full volte-face from a language of win-win thinking and soft power to zero-sum games and strongmen aggression. In comparison to Davutoğlu's IR language, Erdoğan's language comes across as consistently uninfluenced by "soft power" discourse, remaining steadfastly nationalist on the one hand, and committed to Realpolitik in the extreme (or perhaps more accurately, to the politics of mere survival) on the other hand.

\section{Conclusion}

In this paper, we have sought to trace the emergence and the rise and fall of Turkey's "soft power" discourse, and its differential uses by various actors since the beginning of the millennium. We have located the historical roots of the "model" discourse in Turkey's re-orientation towards Central Asia and the Caucasus after the end of the Cold War and situated its re-emergence with an even more extended geo-strategic vision under the Justice and Development Party in the early 2000s. We have highlighted the prominence of American interests in the Turkish model discourse and outlined the 
changing interdependencies between Turkey, the United States, and the European Union in the formation of the discourse. We have flagged the role of Turkish and American think tanks in the process of discourse formation and the centrality of Turkish gatekeepers within this system. And finally, we have shown the overlapping and contradicting elements in this complex discourse involving a range of Turkish and global actors from decision-makers to think-tanks and academics.

The discourse under scrutiny is not only complex, shallow, and at times contradictory, it also demonstrates the extent to which different actors within it have been able to advance their own goals by using it, even if their goals have often been irreconcilable. Particularly at the height of the AKP's power, "soft power" discourse created a discursive space for the regional autonomy of Turkey that was not necessarily in the interests of American foreign policy actors, who above all thought about Turkey's "model role" in self-interested terms, seeking the promotion of American power in the "Arab Spring" countries. This Turkish quest for autonomy and regional hegemony, however, was frustrated by the course of the Arab uprisings and the robustness of the autocratic non-Islamist regimes in Egypt and Syria. It was further undermined by Turkey's domestic challenges and the recent authoritarian turn of the AKP government. Turkey's stellar rise in the Middle East, chided particularly by American and Turkish realists as being too thinly spread and too idealistic, has long surpassed its peak. The consequences of the Syrian conflict, which now play out within the territory of Turkey, and domestic challenges alongside a volatile economy are dampening Turkey's newfound pride and hegemonic ambitions in the region.

With the benefit of hindsight, we now see that the discourses of "model" and "soft power" were shallow and by no means reflective of the real power capabilities of Turkey. Despite the hype created around AKP Turkey that continued well into 2011 and even beyond, Turkey never really came close to becoming a "regional hegemon" or an "order setter" in the Middle East. What Davutoğlu and many foreign policy analysts almost succeeded in establishing, however, was a moment of discursive hegemony, in which an informed foreign policy analysis on Turkey could not be written without ample references to fashionable concepts such as "zero problems with neighbours" or "strategic depth", even though its pan-Islamist and imperialist underpinnings have been discussed in detail (Özkan 2014).

As a final point, we would like to draw attention to the role of academia in the promotion and diffusion of the "Turkish model" and "soft power" discourses. In this paper, we have discussed the generation, modification, and operation of a discourse in a mutually constituted field involving academia, the think-tank community, and foreign policy actors. Neither think tanks, nor foreign policy actors have a mission to deconstruct, enlighten, explain and elucidate power relations, and indeed they have not done so in this case. Academics, at least in the academic tradition the authors of this paper adhere to, do have such a mission. As students of Turkey's foreign policy we are not able to escape the chains of the overarching - if not hegemonic anymore discourses that shape the field we are studying. What we can do, however, is to maintain a critically informed perspective that allows us to see the connectivities and dependencies that the Turkish "soft power" discourse has created. In this sense, the study of Turkey's "soft power" discourse and its "model" role also raises questions about the independence of academic thinking in an intellectual environment structured by overlapping and sometimes contradicting political interests and power 
plays. A significant section of a generation of authors on Turkey's foreign policy have written their papers on Turkey's rise as "soft power" without such second thoughts.

\section{BIBLIOGRAPHY}

Akkoyunlu, Karabekir; Nicolaidis, Kalypso; Öktem, Kerem (2013). Turkey's Western Condition, Oxford, European Studies Centre.

Almassian, Kevork (2014). “The Rise and Fall of Neo-Ottomanism in Syria," Journal of Eurasian Affairs, URL: http://www.eurasianaffairs.net/the-rise-and-fall-of-neo-ottomanism-in-syria/, accessed 1 May 2015.

Aydın, Mustafa (2003). "Between Euphoria and Realpolitik: Turkish Policy toward Central Asia and the Caucasus," in Ismael Tareq; Aydın Mustafa, Turkey's Foreign Policy in the $21^{\text {st }}$ Century: A Changing Role in World Politics, Aldershot, Ashgate, pp. 139-160.

Balc1, Bayram (2005). «Les relations entre la Turquie et l'Asie Centrale turcophone, 1991-2004 », Outre-Terre 10, pp. 297-315. DOI: 10.3917/oute.010.0297.

Bilgin, Ayata (2015). “Turkish Foreign Policy in a Changing Arab World: Rise and Fall of a Regional Actor?," Journal of European Integration 37 (1), pp. 95-112. DOI:

10.1080/07036337.2014.975991.

Bingöl Mcdonald, Deniz (2012). "Imperial Legacies and Neo-Ottomanism: Eastern Europe and Turkey,” Insight Turkey 14 (4) pp. 101-120. URL: http://file.insightturkey.com/Files/Pdf/ insight_turkey_vol_14_no_4_2012_mcdonald.pdf.

Bozdemir, Michel (1991). « La Turquie face à la crise du Golfe », Revue du monde musulman et de la Méditerranée 62, pp. 111-115. DOI: 10.3406/remmm.1991.1474.

Davutoğlu, Ahmet (2013). Teoriden Pratiğe - Türk Dış Politikası üzerine Konuşmalar, Istanbul, Küre Yayınları.

Davutoğlu, Ahmet (2001). Stratejik Derinlik: Türkiye'nin Uluslararası Konumu, Istanbul, Küre Yayınları.

Denzin, Norman K.; Lincoln, Yvonna S. (2011). Handbook of Qualitative Research, Thousand Oaks Ca London, Sage.

Ecevit, Bülent (1999). “An Address by the Turkish Prime Minister," 28 September 1999, Transcript of lecture by Bülent Ecevit at the Washington Institute, URL: http:// www.washingtoninstitute.org/policy-analysis/view/an-address-by-the-turkish-prime-ministerfull-transcript.

Fuller, Graham (2008). The New Turkish Republic: Turkey as a Pivotal State in the Muslim World, Washington, United States Institute of Peace.

Grigoriadis, Ioannis (2010). The Davutoglu Doctrine and Turkish Foreign Policy, Eliamep Working Papers, 8. URL: http://www.eliamep.gr/wp-content/uploads/ 2010/05/\%CE\%9A\%CE\%95\%CE\%99\%CE\%9C\%CE\%95\%CE\%9D\%CE\%9F\%СЕ\%95\%СЕ\%А1\%СЕ\%93\%СЕ\%91\%СЕ\%А3\%CE\%99\%CE\%91\%CE\%A3-8_2010_IoGrigoriadis1.pdf. 
Iğsiz, Aslı (2014). "From Alliance of Civilizations to Branding the Nation: Turkish Studies, Image Wars and Politics of Comparison in an Age of Neoliberalism," Turkish Studies 15 (4), pp. 689-704. DOI: $10.1080 / 14683849.2014 .983689$.

Kalın, Ibrahim (2011). “Soft Power and Public Diplomacy in Turkey," Perceptions 16 (3), pp. 5-23. URL: http://sam.gov.tr/soft-power-and-public-diplomacy-in-turkey/.

Kalın, Ibrahim (February 24, 2006). “Türkiye'nin ince gücü,” Zaman, URL: http:// www.zaman.com.tr/yorum_yorum-dribrahim-kalin-turkiye-nin-ince-gucui_259117.html.

Kennan, George F. (1947). “The Sources of Soviet Conduct,” Foreign Affairs, URL: http:// www.foreignaffairs.com/articles/23331/x/the-sources-of-soviet-conduct\#.

Keyman, Fuat (2012). "Proactivism in Turkish Foreign Policy: The Global-Local Nexus," in Öktem, Kerem; Kadıŏglu, Ayşe; Karlı, Mehmet (eds.), Another empire? A Decade of Turkey's Foreign Policy under the Justice and Development Party, Istanbul, Bilgi University Press.

Kirişçi, Kemal (2009). "The Transformation of Turkish Foreign Policy: The Rise of the Trading State," New Perspectives on Turkey 40, pp. 29-57. DOI: 10.1017/S0896634600005203.

Köse, Faruk (August 26, 2014). “Küresel Sisteme Başkaldırının Anahtarı Hilafet'tir," Yeni Akit, URL: http://www.yeniakit.com.tr/yazarlar/faruk-kose/kuresel-sisteme-baskaldirinin-anahtarihilafettir-7414.html.

Miles, M.; Huberman, A. (1994). Qualitative Data Analysis; an Expanded Source Book, Thousand Oaks $\mathrm{Ca}$, Sage.

Murinson, Alexander (2006). “The Strategic Depth Doctrine of Turkish Foreign Policy," Middle Eastern Studies 42 (6): pp. 945-964. DOI: 10.1080/00263200600923526.

Nye, Joseph S. (2015). Is the American Century Over?, Cambridge, Polity.

Nye, Joseph S. (2004). Soft Power: The Means to Success in World Politics, New York, Public Affairs.

Nye, Joseph S. (1990). Bound to Lead: The Changing Nature of American Power, New York, Basic Books.

Öktem, Kerem (2015). "Strategic Shallows: The End of AKP Power and the Fragmentation of Turkey's Foreign Policy," Südosteuropa Mitteilungen 3-4, pp. 42-50.

Özkan, Behlül (2014). “Turkey, Davutoglu and the Idea of Pan-Islamism,” Survival 56 (4): pp. 119-140. DOI: 10.1080/00396338.2014.941570.

Radikal (December 3, 2011). “Ortadogu'da rejimler sezeryan dogum', Radikal. URL: http:// www.radikal.com.tr/turkiye/ortadoguda_rejimler_sezeryan_dogum-1071417.

Samaan, Jean-Loup (2013). “The Rise and Fall of the "Turkish Model' in the Arab World,” Turkish Policy, URL: http://www.turkishpolicy.com/article/940/the-rise-and-fall-of-the-turkish-modelin-the-arab-world-fall-2013/.

Schreier, Margrit (2012). Qualitative Content Analysis in Practice, London, Sage.

Tuğal, Cihan Ziya (2016). The Fall of the Turkish Model: How the Arab Uprisings Brought Down Islamic Liberalism, London, Verso Books.

\section{NOTES}

1. The working group met at IFEA from December 2013 to March 2014. The authors would like to extend their thanks to Julien Paris, whose Google Scholar research has made a major empirical 
contribution to this paper. Gabrielle Angey, Élise Massicard, Jean-Baptiste Le Moulec, Merve Özdemirkıran, and Jean-François Polo have been of great assistance in the preparation of the empirical references and the broader intellectual framework of this paper.

2. Two methodological biases need to be taken into consideration here: firstly, the self-selection on official websites; and secondly, the self-selection of research engines. To analyse the speeches of Foreign Minister Ahmet Davutoğlu for instance, we downloaded all the speeches available on the Foreign Ministry's website. The selection, therefore, is not based on all speeches Davutoğlu has ever given, but on those speeches selected for the website. As for the second bias, we worked with Internet search engines, such as Google Scholar, which have their own algorithms and data gathering methodologies, which we cannot explain or criticise, but only take as a point of departure for the survey exercise.

3. We used Google Scholar for this search, as this is the most widely used search engine for academic publications. A methodological issue that arises here pertains to the publication date, which in more than 100 cases was not given or was unclear (category "N.C." in Figure 1).

4. In 1987, the EU Parliament declared urs recognition of the Armenian genocide and in 1989, the European Commission issued an unfavourable statement towards Turkey's candidacy.

5. The outcomes of this strategic engagement with the Muslim world lead, inter alia, to the "Pivotal States Project" of the United States Institute of Peace, for Turkey were published in Graham Fuller's 2007 book The New Turkish Republic: Turkey as a Pivotal State in the Muslim World. The term "Pivotal State", however, did not form a discursive dynamic of its own accord and remained a technical term.

6. The Turgut Özal Memorial lectures were instituted in 1997 by the Turkish Research Program of the Washington Institute, founded in 1995. The Turkish Research Program aims to analyze the Turkish political scene and its impacts on both US interests and American-Turkish bilateral relations.

7. The Abant Platform is a non-state institution organizing meetings and forums on sociopolitical issues. The Abant Platform is supported by the Journalist and Writers Foundation, an organization known to be supportive of the Gülen Movement and hence losing its government connections after a fall out between the movement and the ruling party in December 2013.

8. A search through the Ministry of Foreign Affairs website's internal search engine revealed 32 entries for the period between 2007 and 2013. Most of these entries are speeches, interviews, and newspaper articles by Ahmet Davutoğlu, Naci Koru (Deputy Foreign Minister since 2012), ambassadors located in five world capitals, and former Foreign Ministers Ali Babacan and President Abdullah Gül. There are also some background papers on the MFA and two speeches by counsellor generals. While the documents on the website are clearly selected, and hence not necessarily exhaustive, we can assume that they were chosen by the MFA and, therefore, can be considered as representative of the messages the MFA intends to project. In contrast, the Turkish-language website of the Prime Minister's website only delivers three entries, which are also discussed.

9. We need to note here, that coinciding with the development of the Syrian crisis and the AKP government's decision to take a more belligerent stance towards Syria and its own Kurdish movements, the promise of a consensus-seeking language has been abandoned in favor of the language of threats.

10. The data analysis was executed with voyant-tools.org as part of a quantitative discourse analysis. The initial analysis was carried out based on a word document containing a total of 75 speeches available from the website of the Ministry of Foreign Affairs. The word list was simplified by combining synonymous entries, plural and singular forms of the same word, as well as nouns and adjectives (i.e. peaceful and peace; Bosniak and Bosnia; Islam, Muslim and Muslims). Additional search terms, which were expected in the initial analysis of voyant-tools but did not produce any results, were subsequently searched manually in the text. The initial outcome of the 
first analysis can be found here in form of a comprehensive word cloud, URL: http://voyanttools.org/tool/Cirrus/? corpus=1392658211629.6145\&query=\&stopList=stop.en .taporware.txt\&docIndex=0\&docId=d1392613252590.fe54cb51b0ae-83dc-320c-d758cf849d98.

11. A comparable diagram with the countries mentioned does not give a meaningful insight as it is biased towards political crises and conflicts (hence the three top countries are Syria, Palestine, and Iraq), and less so towards underlying interests or ideological choices.

\section{ABSTRACTS}

Since the coming to power of the Justice and Development Party [Adalet ve Kalkınma Partisi, AKP] in 2002, Turkish foreign policy has witnessed significant changes. After the euphoric years of foreign policy pro-activism geared towards the global expansion of Turkey's influence, domestic and regional developments have raised questions concerning Ankara's capacity to achieve its ambitious foreign policy goals. Parallel to the "rise and fall" of Turkish foreign policy, a similar cycle can be observed regarding the discourse on Turkey's "soft power". This paper seeks to appraise Turkey's "soft power" and "model" discourses by establishing the chronology of their emergence and highlighting the multidimensional structure of their production. The authors argue that the discourses on Turkey's "soft power" are created within a triadic system of discourse production. This system works through the domains of think tanks, academia, and foreign policy actors in Turkey and beyond. These domains are bound to each other through reciprocal relations of interest and are negotiated by gatekeepers, i.e. well-connected persons of influence. Turkey's "soft power" discourse is as much a product of Turkish foreign policy itself as it is a product of Turkey's relations with the United States (US). Circulating through these different domains, and being appropriated by a large number of actors with differing and sometimes contradictory interests, these discourses, reconstructed by the authors in this study, are highly permeable, diverse, and unstable. For a brief period, they did, however, collectively contribute to the emergence of an almost hegemonic discourse on Turkey's soft power, thereby reinforcing the AKP regime at the beginning of the 2010s.

\section{INDEX}

Keywords: Soft power, foreign policy, Turkish model, think tanks, discourses, Neo-Ottomanism, Islamism, Justice and Development Party

\section{AUTHORS}

\section{YOHANAN BENHAÏM}

PhD Candidate Paris 1 Panthéon Sorbonne University French Institute of Anatolian Studies (IFEA), Istanbul yohanan.benhaim@live.fr 


\section{KEREM ÖKTEM}

Professor for Southeast European Studies and Modern Turkey, Graz University

Associate of the Centre for International Studies, University of Oxford

kerem.oktem@uni-graz.at 